$12-2017$

\title{
Prismatic Blade Production in the Lower Cacaulapa Valley, Honduras: Implications for a Late Classic Political Economy
}

William J. McFarlane

Johnson County Community College, mcfarlane@jccc.edu

Edward M. Schortman

Kenyon College

Follow this and additional works at: https://scholarspace.jccc.edu/anthpp

Part of the Archaeological Anthropology Commons

\section{Recommended Citation}

McFarlane, William J. and Schortman, Edward M., "Prismatic Blade Production in the Lower Cacaulapa Valley, Honduras: Implications for a Late Classic Political Economy" (2017). Anthropology Papers and Presentations. 5.

https://scholarspace.jccc.edu/anthpp/5 


\title{
PRISMATIC BLADE PRODUCTION IN THE LOWER CACAULAPA VALLEY, HONDURAS: IMPLICATIONS FOR A LATE CLASSIC POLITICAL ECONOMY
}

\author{
William J. McFarlane and Edward M. Schortman
}

\begin{abstract}
Investigations of ancient political economies frequently focus on craft production. How manufacturing is organized can provide critical insights on more than the economy because social interactions and political processes are also involved. Here we consider how the acquisition, fabrication, and distribution of obsidian blades figured in the political strategies of craftworkers and elites within the Late Classic (AD 600-800) lower Cacaulapa Valley, northwestern Honduras. This evidence provides insights into the organization of craft manufacture across southeastern Mesoamerica and suggests that current models do not capture the varied production strategies that may be pursued within the same polity.
\end{abstract}

Las investigaciones sobre las economías políticas de los antiguos Mayas se enfocan frecuentemente en la producción artesanal. El modo de organización del proceso de manufactura nos puede proporcionar una visión crítica que va más allá de la economía, debido a que involucra múltiples interacciones sociales y políticas. En este trabajo consideramos cómo la adquisición, fabricación y distribución de navajas de obsidiana formó parte de las estrategias políticas de los artesanos y las élites del Clásico tardío (600-800 dC) en el valle inferior de Cacaulapa, en el noroeste de Honduras. Esta evidencia arroja una imagen de la organización de la manufactura artesanal en el sureste de Mesoamérica y sugiere que los modelos actuales no encapsulan las múltiples estrategias de producción que pueden perseguirse dentro de una entidad política.

$\mathrm{A}$ rchaeological analyses of political economies tend to highlight how elites manipulate production, distribution, and consumption processes to enhance their power over the actions of others. Efforts to counter such top-down pretensions attribute more agency to commoners, modeling the ways in which they employed these economic processes in efforts to exercise the power to define and achieve their own aims (Saitta 1994; Wolf 1990).

Craft production (fashioning goods for exchange with those outside an artisan's household) has figured prominently in these discussions (Clark and Parry 1990; Costin 1991, 2001; Schortman and Urban 2004a). For example, some have contended that efforts to concentrate power may be enabled by exclusive elite control over the manufacture and exchange of generally needed resources (Brumfiel 1994; Brumfiel and Earle 1987; Hirth 1996). The monopolists thereby create a hierarchically structured social net in which subordinates are bound to leaders by enduring debt relations (Brumfiel and Earle 1987; Ekholm 1972; Friedman and Rowlands 1978).

People may frustrate these strategies by acting to secure essential items and knowledge on their own terms, by their own efforts (Brumfiel and Earle 1987; Dietler 2010; Gosden 2004). Crafts and the skills and materials needed to pursue them are acquired and put to work through social connections that are not captured and controlled by a few magnates.

The former perspective presupposes highly centralized economies in which attached artisans fashion some items that distinguish rulers from subjects as well as other objects that are redistributed in displays of elite largesse intended

William J. McFarlane — Anthropology Department, Johnson County Community College, 12345 College Blvd., Overland Park, KS 66210, USA (mcfarlane@jccc.edu)

Edward M. Schortman — Anthropology Department, Palme House, Kenyon College, Gambier, OH 43022, USA

Latin American Antiquity 28(4), 2017, pp. 577-598

Copyright (C) 2017 by the Society for American Archaeology doi:10.1017/laq.2017.53 
to constitute and legitimize inequality (Brumfiel and Earle 1987; Clark and Parry 1990; Costin 1991, 2001; Feinman 1995; Peregrine 1991). The latter formulation posits the existence of independent craftworkers who exchange their output largely free of elite intervention, often through markets (Bernier 2010; Costin 1991; Garraty 2009, 2010; Hirth 1998, 2008, 2010, 2013; Masson and Freidel 2002).

These arrangements comprise two points within a matrix of socioeconomic possibilities defined by how people realize goals as they make, exchange, and use goods within and across social nets. As many have noted (e.g., Feinman 2013; Hirth 1996, 1998; Rice 2009), the resulting socioeconomic configurations often combine varying means of accomplishing all three highlighted tasks (Stark 1992; Stark and Garraty 2010). Grasping how craft production figured in these complex structures requires specifying who made particular items and at what scales and levels of intensity. Further, it is important to know which techniques were employed to transform the raw materials and how the goods were used and distributed. Questions of what economic and political benefits accrued to the craftworkers and under what political constraints, if any, they operated must also be answered (Costin 1991, 2001). We will address these queries for the Late Classic (AD 600-800) lower Cacaulapa Valley in northwestern Honduras (Figure 1), where survey and excavation at a wide range of settlements have revealed a complex political economy that defies easy categorization.

\section{The Lower Cacaulapa Valley}

The Cacaulapa River, a perennial southern tributary of the Rio Chamelecon, cuts a narrow defile through steeply sloping hills. The $14 \mathrm{~km}^{2}$ lower valley is characterized by small expanses of arable land situated on narrow river terraces and in diminutive upland valleys. Survey of the basin revealed $7 \mathrm{~km}^{2}$ of agriculturally productive tracts, the largest extent of suitable farmland being less than $1 \mathrm{~km}$ wide. The archaeological resources of the area are known through six seasons of research beginning in 1999 during which 57 sites in the basin were recorded, 10 sites were excavated, and roughly 170,000 artifacts were analyzed (McFarlane 2005; Urban 2007; Urban et al. 1997; Urban et al. 2013; Wells 2003). The primary focus of these investigations has been the site of El Coyote. With 415 buildings, this center was more than 14 times the size of the next largest contemporary. Indeed, the 21 coeval settlements found beyond El Coyote consist of artifact scatters and small households of no more than 28 constructions (Figure 2).

Occupation began at El Coyote by the Middle Preclassic (1200-400 BC), the site becoming a regional capital in the Late Classic. During the latter interval, El Coyote was dominated by a monumental core (Figure 3 ) organized according to principles identified in the Maya Lowlands; that is, a transition from sacred public spaces to secluded, elite domestic ones moving north to south (Ashmore 1987, 1991; Ashmore and Sabloff 2002; cf. Joyce et al. 2009). The rectilinear, plaster-floored main plaza covers 5,000 $\mathrm{m}^{2}$ and is entered on the northeast by a causeway that extends $250 \mathrm{~m}$ to the north. Lying to the south are two ball courts, constricted plazas, and densely nucleated sizable platforms, likely elite residences, access to which was restricted. Smaller domestic platforms that housed people of lower ranks are concentrated south of the monumental core.

This settlement hierarchy strongly indicates that power during the Late Classic was concentrated at El Coyote, specifically within its epicenter. How economic processes figured in these political developments is complicated.

\section{Crafting at El Coyote}

Production at El Coyote appears in two forms: pottery production and work-party feasts.

\section{Pottery Production}

Though no firing facilities have been identified at the center, several lines of evidence indicate that pottery vessels were fabricated in southern El Coyote. First, Late Classic ceramics found throughout the lower Cacaulapa Valley are made from pastes that are macroscopically distinct from those characterizing vessels made in the coeval Naco and middle Chamelecon Valleys immediately to the northeast. Second, excavations on El Coyote's southeast edge recovered 


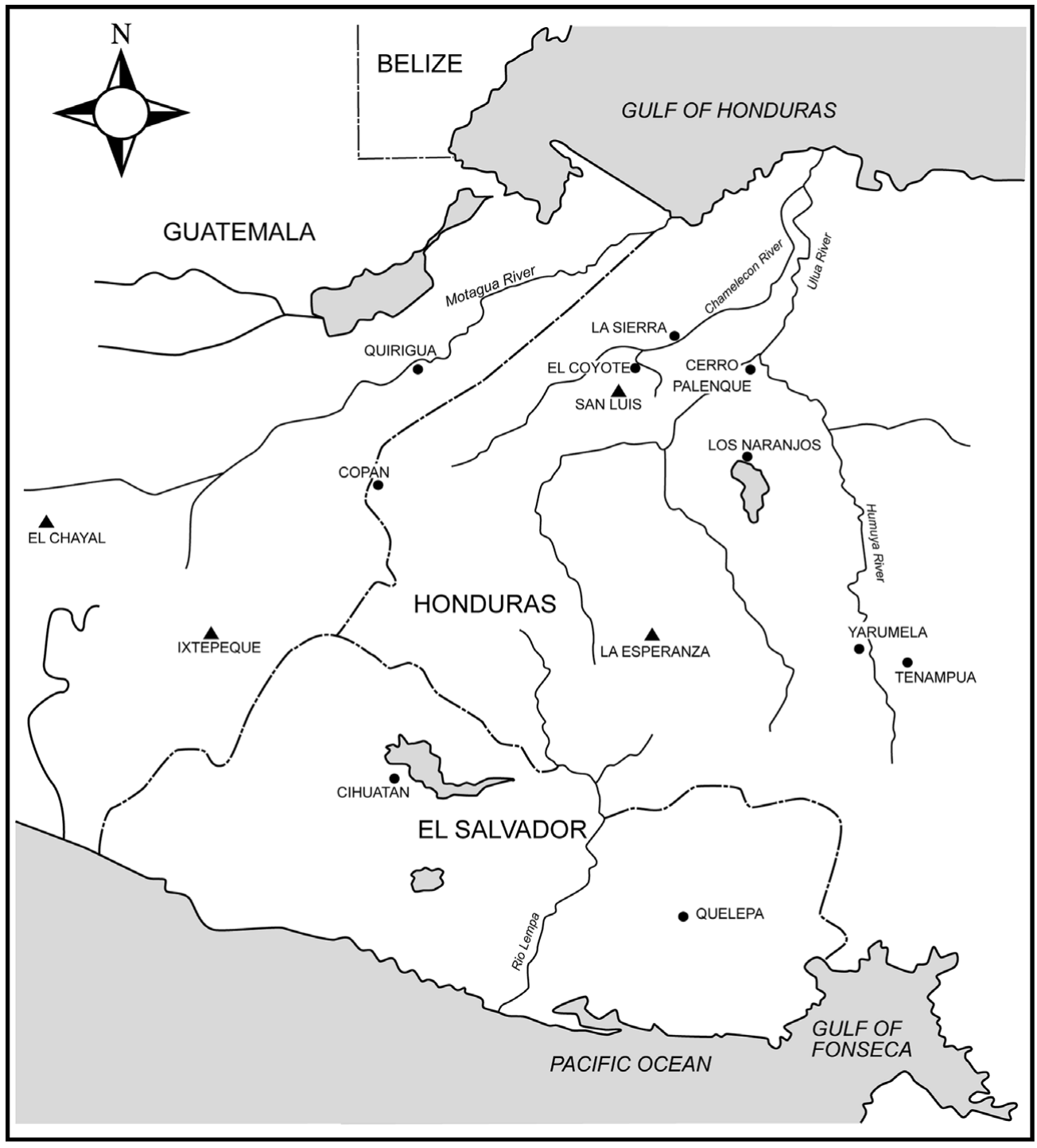

Figure 1. Location of the lower Cacaculapa Valley and obsidian sources.

a dense deposit of sherds, ash, and ceramic fragments modified for use in shaping pots $(3,526$ pieces $\left./ \mathrm{m}^{3}\right)$. Finally, a historical period oven for firing ceramic roof tiles was found nearby, suggesting that pottery production using local clays was feasible at the center.

Though not definitive, these observations suggest that pottery vessels were made at El Coyote during the Late Classic. Most likely, the containers were manufactured on a relatively small scale by artisans residing in southeastern El Coyote, their outputs exchanged with consumers in the center and its hinterland. There is no evidence that these processes of production and distribution were under elite control, nor do they seem to have resulted in elevated status or power for the artisans.

\section{Work-Party Feasts}

Political centralization at El Coyote was apparently initiated, in part, through activities conducted in the site core. The very form of the epicenter reinforced status distinctions in that passage, through its various components, became 


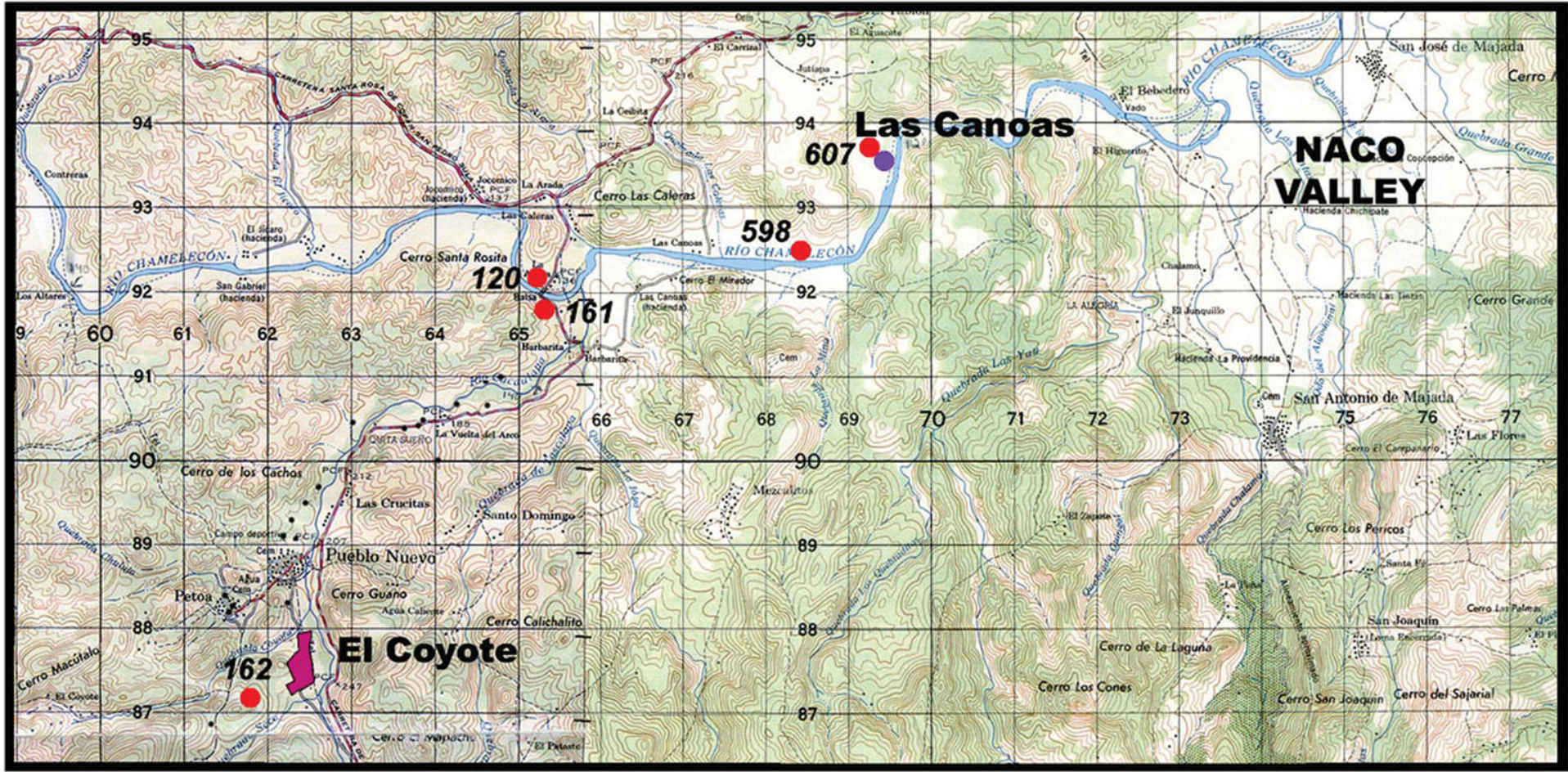

Figure 2. Settlement map indicating El Coyote, Site PVC162, and other sites. (Color online)

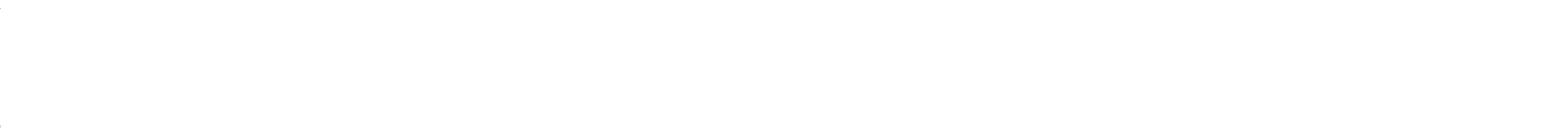




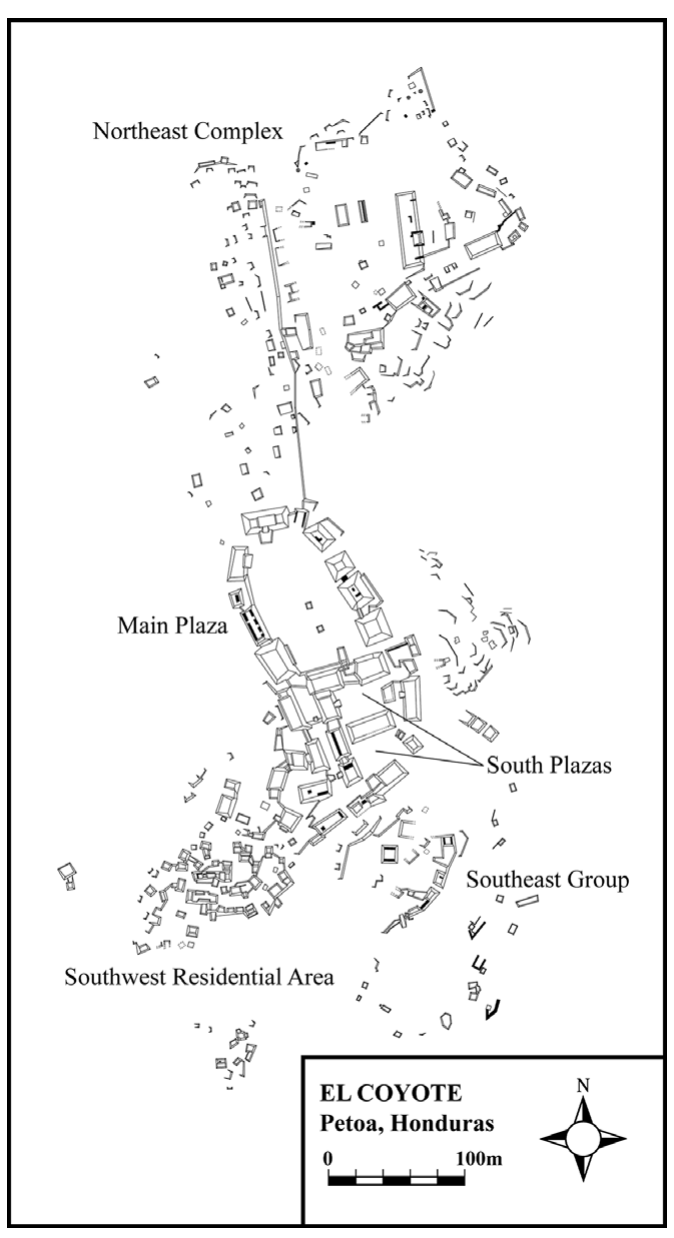

Figure 3. Structure map of El Coyote.

increasingly restricted as people moved south from the main plaza into secluded areas of elite residence and ritual (the latter conducted in the ball courts located here; Moore 1996; Stockett 2005). The extensive plaza likely hosted public rites performed by the rulers of El Coyote.

Wells's investigations in the main plaza (2003, 2004, 2007, 2010) strongly indicate that these observances were associated with feasts where food and chicha were prepared and consumed by participants. Those producers were not craftworkers, as they were engaged in common domestic tasks, albeit at large scales, the surpluses being used and consumed by fellow participants in public gatherings. Nonetheless, workparty feasts required the coordinated, if episodic, labor of numerous people presumably directed by rulers. The latter probably benefited from these celebrations as they placed themselves at the center of rites and feasts that instantiated a social affiliation uniting the entire populace (Schortman and Urban 2011; Wells 2006).

\section{Summary}

Evidence from El Coyote suggests that the Late Classic political economy of the lower Cacaulapa Valley consisted primarily of a domestic mode of production. The economy functioned to meet the basic physical needs of households and periodically to produce large quantities of food and drink to support public gatherings directed by elites in the central plaza. These feasts were coupled with religious rites through which a valley-wide identity, and the prominence of the rulers who led it, were reproduced and celebrated.

Pottery vessels and obsidian blades were essential to the tasks by which households and hierarchies were sustained. The former were seemingly fabricated for local consumption at the center by artisans who may have operated independently of elite control. Obsidian blades were equally ubiquitous parts of assemblages associated with buildings of all sizes and locations within the lower Cacaulapa Valley. Unlike pottery, however, through 2004 there was no evidence that blades were fashioned in the basin. It seemed that these implements were imported, some measure of elite power possibly deriving from control over their acquisition and local distribution. This interpretation was definitively disproven during investigations at Site PVC162.

\section{Site PVC162}

Site PVC162 (Figure 4) consists of four modest structures arranged around a patio with three low terraces trailing off downhill to the northeast. It was first recorded during the initial valley survey and excavated in 2004 (McFarlane et al. 2005; Urban 2007). Located $1.5 \mathrm{~km}$ southwest of El Coyote, Site PVC162 was singled out for investigation because of its locally unusual placement atop a hill some $75 \mathrm{~m}$ above and overlooking the terrace occupied by that center. The ground here slopes down southwest to northeast, dropping 


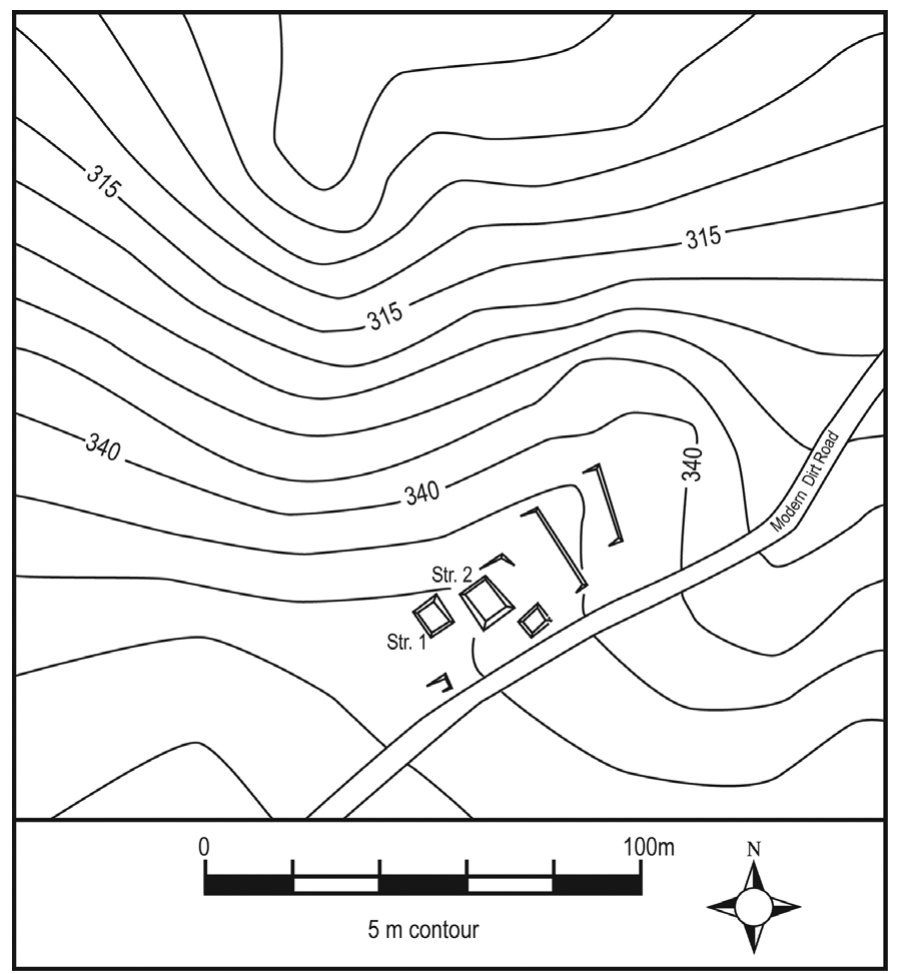

Figure 4. Site map of Site PVC162 and topography.

precipitously into steep-sided ravines immediately northwest and southeast of the settlement.

Aside from a commanding view, the location of Site PVC162's location holds few obvious advantages. There is no easy passage to the only perennial water source, the Rio Cacaulapa, 1.25 $\mathrm{km}$ to the east. Today, soils in the immediate vicinity of the site are thin, and there is no evidence to suggest that farming conditions would have been more favorable during the Late Classic. As Urban (2007:48) noted, "Site PVC162 seemed admirably located to make meeting the needs of daily life as difficult for its inhabitants as possible."

The two largest structures were investigated through excavations exposing $73.5 \mathrm{~m}^{2}$ of architecture and surrounding ground surface, which unearthed a combined volume of $22.9 \mathrm{~m}^{3}$ (11.6 $\mathrm{m}^{3}$ from Structure 1 and $11.3 \mathrm{~m}^{3}$ from Structure 2). Analyses of recovered artifacts indicate that occupation of Site PVC162 was largely limited to the Late Classic, the settlement being abandoned early in the Terminal Classic (AD 800-
1000). Throughout this period, the investigated structures underwent multiple episodes of significant architectural alteration (Figure 5). The widespread use of shaped limestone masonry in both buildings is notable as this practice is rarely recorded outside the main plaza of El Coyote.

Structure 1 was remodeled at least four times. An early circular or semi circular limestone surface was succeeded by a $0.35-0.58 \mathrm{~m}$ tall, stone-faced and -filled platform that covered $7.1 \mathrm{~m}^{2}$ and was aligned $128^{\circ}$ (i.e., roughly NW-SE; Figure 6). This construction supported two rooms and faced to the southwest. Subsequent modifications made to Structure 1 likely correspond to the construction of Structure 2 . The addition of a $0.1 \mathrm{~m}$ high cobble terrace doubled the basal dimensions of this building and reoriented Structure 1 to the plaza on the northeast. Finally, rooms were erected on the ancient ground surface along all sides of the building save the northeast.

The earliest version of Structure 2 was a 0.50 $0.86 \mathrm{~m}$ high basal platform that encompassed 


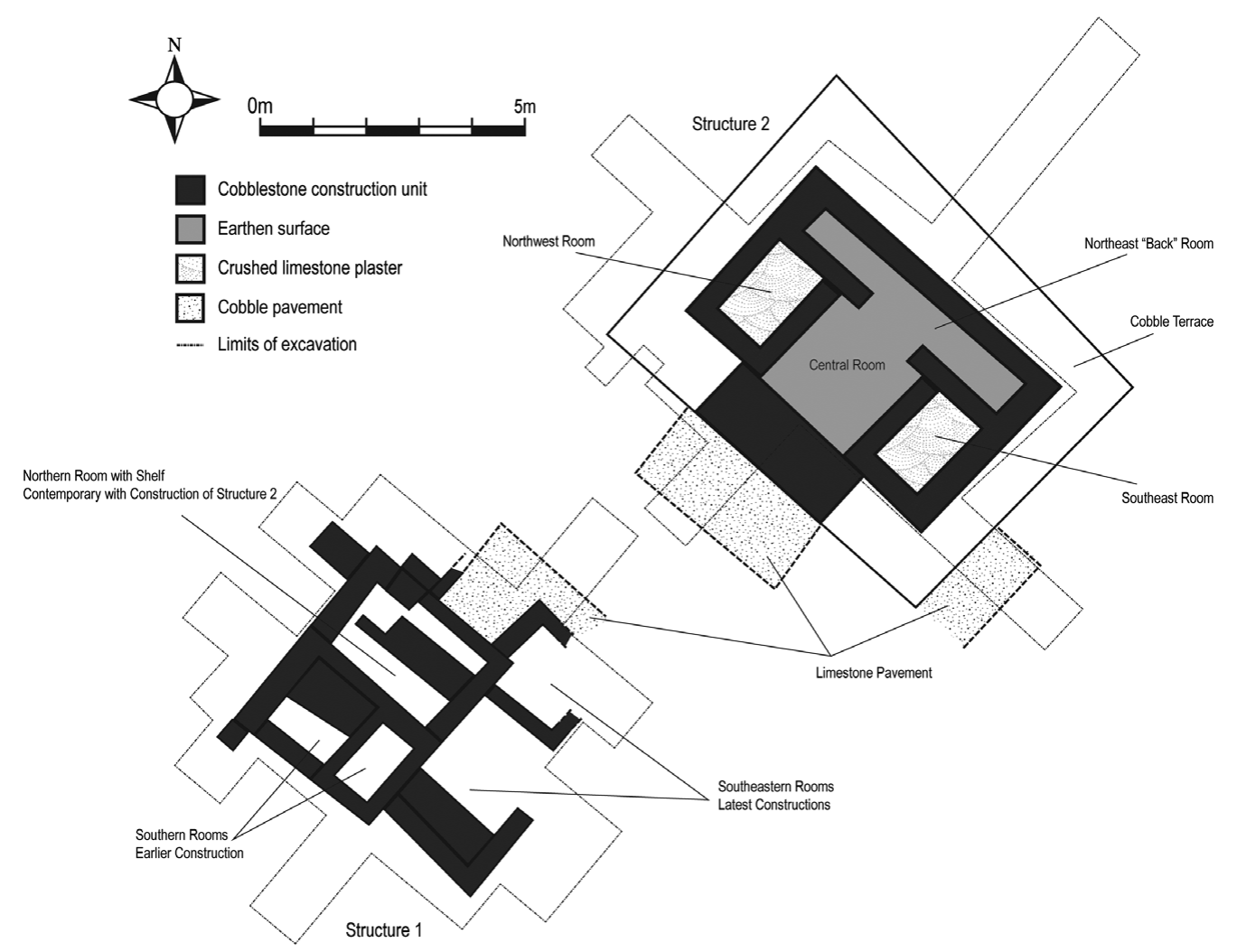

Figure 5. Map with excavation limits and construction units.

$23.4 \mathrm{~m}^{2}$ and was aligned $130^{\circ}$. Three of the four rooms are set in a line overlooking the patio and are backed on the northeast by the narrow (0.5 m wide) fourth compartment (Figure 7). A step that projects into the patio provided entry to the central room of Structure 2. This enclosure was surfaced with earth as was the back, northeast compartment to which it leads. The northwest and southeast rooms were floored with a white crushed limestone plaster. Burned patches on the plaster surfaces in both cubicles suggest the intermittent use of a hearth or incense burners. Plaster-floored rooms are unknown in the lower Cacaulapa Valley beyond El Coyote's monumental core.

Subsequently, the basal platform of Structure 2 was expanded to cover $49.1 \mathrm{~m}^{2}$ by the construction of a $0.26-0.45 \mathrm{~m}$ tall cobble terrace that was raised on all sides of the edifice. The final construction efforts sealed the summit rooms. The northwest and southeast compartments were filled with a very soft clay brought in from off- site, then the whole summit was raised using a mix of rocks and earth. This fill episode thus erased earlier divisions and possibly created one large room atop the platform.

\section{Building Functions}

The architecture and associated material assemblage indicate that Site PVC162 housed a yearround occupation. Structure sizes and forms are comparable to those identified as residences and outbuildings in Late Classic lower Cacaulapa Valley households. Artifacts were collected from various contexts, including terminal debris, fill, and a large midden lying between the northwestern faces of both buildings and the steep drop to the river. Artifact densities $\left(177 / \mathrm{m}^{3}\right.$ overall) generally match those seen at other Late and Terminal Classic domiciles recorded in this and adjacent valleys.

There are slight discrepancies between the assemblages of Structures 1 and 2. The larger 

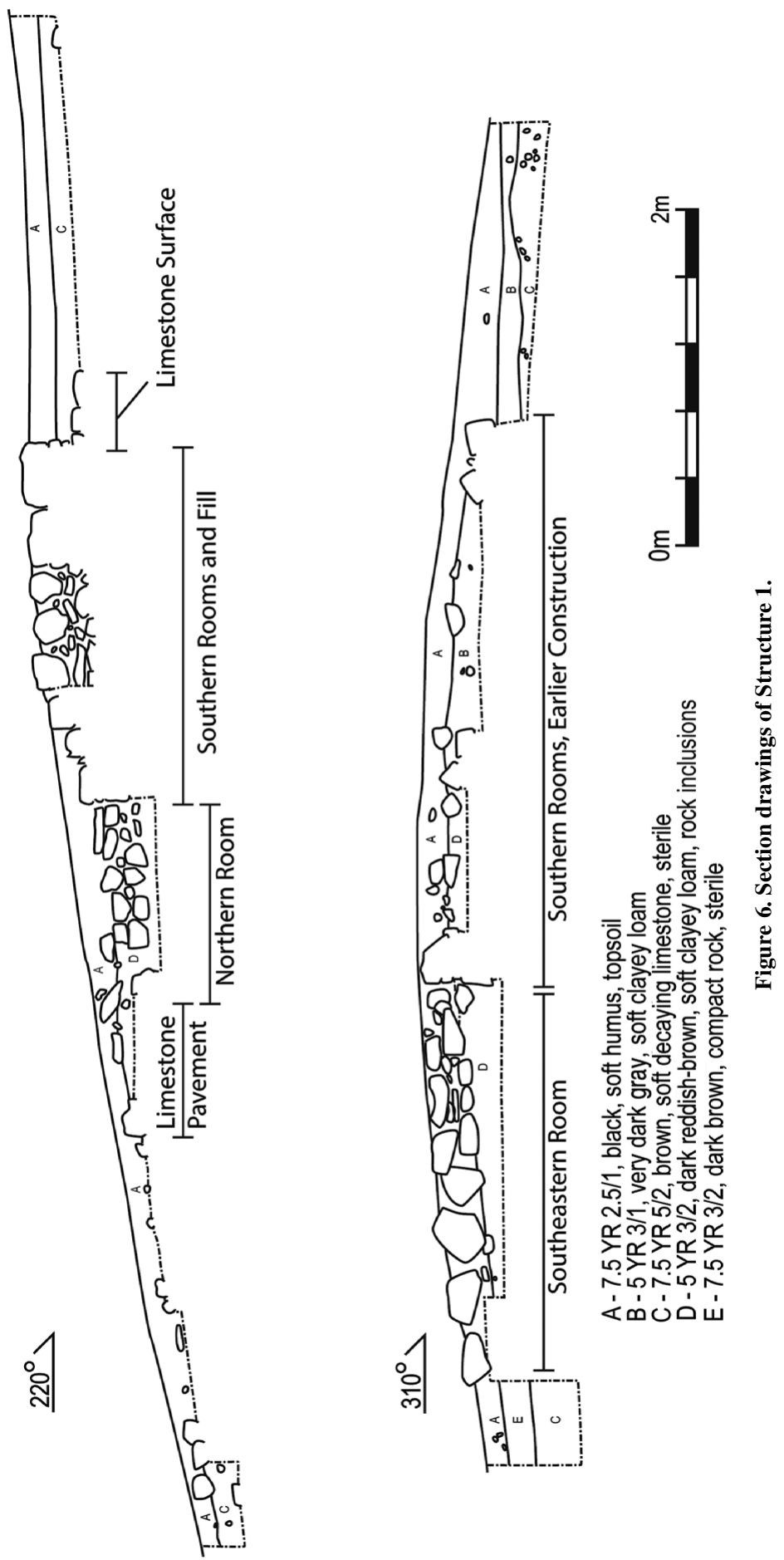


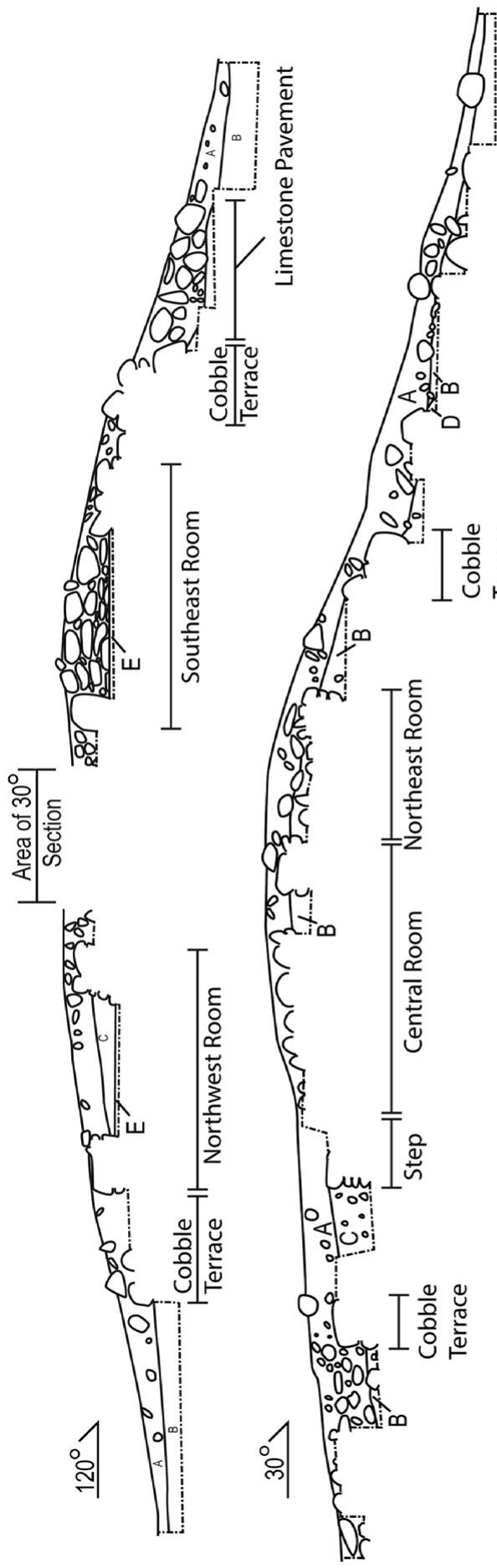

 
Structure 2 has the more typical domestic collection. For example, it has marginally more incense burners (three) than does Structure 1 (one) and possesses paraphernalia related to daily activities, such as grinding stones and figurines, which are absent from Structure 1. The midden associated with Structure 2 also yielded far more freshwater snails (Pachychilus sp.) than did any context on and around Structure 1, possibly hinting that food processing was more common here than at its southwestern neighbor.

The ceramic assemblage from Structure 2 is also richer in elaborately decorated or imported ceramics (EDICs) than is the case for materials associated with Structure 1. Of the 891 analyzed sherds from terminal debris contexts at Structure $2,9 \%$ are from these presumably high-value items. Their frequency increases if we take into account the building's midden where $19 \%$ of the 489 analyzed sherds were EDICs. Only 1\% of ceramics from terminal debris contexts of Structure 1 and 3\% from its midden are EDICs $(N=326$ and 117).

There are also marked differences in the relative amounts of jars and bowls between the investigated constructions. Of the 79 analyzed rims from the terminal debris deposits of Structure 2,70\% are from bowls, whereas at Structure 1, jars predominate (52\% of 29 studied rims). The midden collections follow the same pattern; $74 \%$ of 53 analyzed rims from trash at Structure 2 are bowls, whereas jars make up $53 \%$ of the analyzed rims $(N=13)$ from the Structure 1 midden. The proportion of bowls and jars at Structure 1 conforms to patterns seen in Late and Terminal Classic domestic buildings in the lower Cacaulapa and neighboring valleys where evidence for food storing and serving are more or less equally represented (Schortman and Urban 2004b). The relatively small sample sizes urge caution in their interpretation. Nonetheless, differences in vessel forms could point to a concentration of food serving and preparation in and around Structure 2, while the storage of comestibles was centered in Structure 1.

\section{Summary}

Analyses of architecture and artifacts from Site PVC162 suggest that the settlement was occupied year-round and underwent significant reno- vations during the Late and very early Terminal Classic. Although the investigated buildings are contemporaries, there is variation in the activities conducted in each. Structure 1 served as a residence in which curating food and drink were significant activities. Structure 2 may have been a relatively exalted venue where select domestic tasks were pursued, such as food preparation and serving. The small sizes of the rooms of Structure $2\left(2.0-4.8 \mathrm{~m}^{2}\right)$ and lack of built-in furniture implies that some residential activities, including sleeping, were relegated to other locales including Structure 1, where benches are attested. The social significance of sharing comestibles at Structure 2 was possibly enhanced by the relatively imposing appearance of the structure and the elaborate paraphernalia employed in these tasks. Structure 2, therefore, may have been a focal point for dramatic episodes of food sharing that united the residents of Site PVC162 but that might not have privileged the occupants of any one domicile. Feasting may thus have helped constitute social identities at El Coyote and Site PVC162, albeit at distinct scales and with divergent political consequences.

The occupants of Site PVC162 were people of relatively high status who exercised considerable control over skilled and unskilled labor. The selective application of plaster and extensive use of cut blocks, materials not commonly seen outside the Late Classic core of El Coyote, are striking indicators of social preeminence (Wells 2006). The high frequencies of EDICs found here, unmatched elsewhere in the Late Classic lower Cacaulapa Valley even at El Coyote, is suggestive of significant prosperity. We argue that the prominence of these hilltop dwellers throughout the Late Classic is associated with their roles as producers of obsidian blades.

\section{Blade Production and Site PVC162}

The recovery at Site PVC162 of 82 exhausted prismatic blade cores along with numerous prismatic blades and debris related to their production raised questions about how the settlement's residents fit within the Late Classic political economy of the lower Cacaulapa Valley and how their roles in that structure changed over time. To address these queries, we consider 
Table 1. Obsidian Artifacts Tabulated by Source and Technological Classification.

\begin{tabular}{|c|c|c|c|c|c|c|c|c|c|c|c|c|}
\hline \multirow[t]{2}{*}{ Classification } & \multicolumn{2}{|c|}{ Ixtepeque } & \multicolumn{2}{|c|}{ Chayal } & \multicolumn{2}{|c|}{ San Luis } & \multicolumn{2}{|c|}{ Perlite } & \multicolumn{2}{|c|}{ Unsourced } & \multicolumn{2}{|c|}{ Subtotal } \\
\hline & \# & (g) & $\#$ & $(\mathrm{~g})$ & $\#$ & (g) & $\#$ & $(\mathrm{~g})$ & $\#$ & (g) & \# & (g) \\
\hline Unworked Nodules & - & - & - & - & - & - & 2 & 5.2 & - & - & 2 & 5.2 \\
\hline Percussion Cores & 2 & 41.0 & - & - & - & - & 1 & 1.6 & - & - & 3 & 42.6 \\
\hline Bipolar Cores & 3 & 12.9 & - & - & - & - & - & - & - & - & 3 & 12.9 \\
\hline Percussion Flakes & 46 & 65.6 & 1 & 0.5 & 26 & 206.0 & 17 & 18.6 & - & - & 90 & 290.7 \\
\hline Percussion Blades & 1 & 0.6 & - & - & 4 & 13.1 & 1 & 0.3 & - & - & 6 & 14.0 \\
\hline All Expedient & 52 & 120.1 & 1 & 0.5 & 30 & 219.0 & 21 & 25.6 & - & - & 104 & 365.3 \\
\hline Prismatic Cores & 42 & 1730.0 & - & - & 8 & 461.4 & - & - & 32 & 1004.6 & 82 & 3196.0 \\
\hline Prismatic Blades & 448 & 522.7 & 9 & 7.2 & 16 & 15.5 & - & - & - & - & 473 & 545.4 \\
\hline Initial Series Blades & 1 & 13.4 & - & - & 1 & 18.2 & - & - & - & - & 2 & 31.6 \\
\hline Initial Series Flakes & - & - & - & - & 1 & 6.1 & - & - & - & - & 1 & 6.1 \\
\hline Second Series Flakes & 103 & 191.6 & - & - & 2 & 5.1 & - & - & - & - & 105 & 196.7 \\
\hline $\begin{array}{l}\text { Platform Rejuvenation } \\
\text { Flakes }\end{array}$ & 11 & 24.6 & - & - & 7 & 302.3 & - & - & - & - & 18 & 326.9 \\
\hline Distal Rejuvenation Flakes & 7 & 24.8 & - & - & - & - & - & - & - & - & 7 & 24.8 \\
\hline $\begin{array}{l}\text { Indeterminate } \\
\text { Rejuvenation Flakes }\end{array}$ & 14 & 20.6 & - & - & - & - & - & - & - & - & 14 & 20.6 \\
\hline All Blade Production & 626 & 2527.7 & 9 & 7.2 & 35 & 808.5 & - & - & 32 & 1004.6 & 702 & 4348.0 \\
\hline Indeterminate & 53 & 32.1 & - & - & 14 & 16.1 & 3 & 3.7 & - & - & 70 & 51.9 \\
\hline TOTAL & 731 & 2680.0 & 10 & 7.7 & 79 & 1043.7 & 24 & 29.3 & 32 & 1004.6 & 876 & 4765.2 \\
\hline
\end{tabular}

three main points. First, how was the technology of prismatic blade production organized at Site PVC162? Second, how was the workshop integrated within local and regional production and exchange relations? Finally, how did these practices of manufacture, consumption, and distribution shift over time in relation to political processes operating at multiple spatial scales?

\section{Methods}

Fully 876 chipped obsidian artifacts (55 chert artifacts are excluded from this analysis) were recovered from Site PVC162 (Table 1). All of the material was classified using a behavioral or technological typology (Clark 1997; Clark and Bryant 1997; Sheets 1975). This scheme classifies artifacts by their method of manufacture and is well suited for revealing the structure of lithic industries. More importantly, each artifact can be assigned to a specific segment of a reductive sequence, thereby facilitating inferences concerning where and at what scales and intensities stone tool manufacture was pursued. The popularity of this approach across Mesoamerica is due partly to its facility in designating each chipped stone specimen by its use-life trajectory, behavioral stage, and place in a chaîne opéra- toire (Braswell 2004; Hirth 2003:5; MoholyNagy 2011; Schiffer 1972; Sheets 2003). This approach also reveals much about how these technological systems articulated with the political economy.

In addition to classifying each artifact, key attributes were recorded to place the specimens within the reductive sequence of the industry. Noted attributes include the presence or absence of cortex, platform treatment, segment of the artifact, presence or absence of retouch, macroscopic assessment of use-wear or edge damage, and weight. With the exception of indeterminate shatter, maximal length, width, and thickness were also recorded.

Geological sources were determined visually (Braswell et al. 2000). Because the exhausted blade cores were too thick for confident application of this method, 50 nuclei were submitted to the Archaeometry Laboratory at the University of Missouri Research Reactor. The cores were subjected to energy dispersive X-ray fluorescence and neutron activation analysis. Nodules of perlite, volcanic ejecta with a thoroughly hydrated cortex, were also noted. Having virtually the same properties as obsidian, these nodules could have been collected along the Cacaulapa River 
Table 2. Distribution of Blades and Production Debris by Contexts, Site PVC162.

\begin{tabular}{|c|c|c|c|c|c|c|}
\hline & \multicolumn{3}{|c|}{ Structure 1 (excav. vol. $11.6 \mathrm{~m}^{3}$ ) } & \multicolumn{3}{|c|}{ Structure 2 (excav. vol. $11.3 \mathrm{~m}^{3}$ ) } \\
\hline & Midden & SE Room & All Contexts & Midden & SE Room & All Contexts \\
\hline Exhausted Blade Cores* & 12 & 7 & 34 & 14 & 24 & 46 \\
\hline Production Debris & 21 & 8 & 66 & 26 & 6 & 82 \\
\hline Finished Blades & 65 & 23 & 179 & 137 & 27 & 293 \\
\hline
\end{tabular}

* Two exhausted blade cores were collected from a nearby roadcut, and although they are clearly associated with this site, they cannot be assigned to either of these structures.

and from tuff deposits in the vicinity of El Coyote.

\section{Organization of Blade Production at Site PVC162}

The evidence from Site PVC162 reveals much about the organization of blade production at this workshop. Raw material was acquired through long-distance exchanges as well as from local outcrops. Although blades were produced at the workshop, very few of these goods were consumed or discarded here. Techniques for knapping blades varied over time and also by obsidian source. These patterns of variation suggest that, prior to the abandonment of the household, regional obsidian exchange networks had destabilized, necessitating the implementation of an alternative production technique.

Prismatic blade segments and blade production debris were scattered throughout the excavations. Blade production was a consistent activity throughout the occupation of Site PVC162, and the assemblage does not represent a single episode of craft production activity. Concentrations of debris were noted within the southeastern rooms of both excavated structures and along the northwestern base of each platform (Table 2). This pattern suggests that production activities may have been conducted indoors, while waste material was commonly disposed in middens along the edges of the buildings, presumably to wash down the steep decline. It is important to note that these midden deposits also include non-production waste such as pottery and other paraphernalia discarded through the course of daily activities. Apparently, materials associated with blade production were not conceptualized as distinct from household detritus.
The results of sourcing analysis demonstrate that obsidian from the Ixtepeque flows was the most frequently imported material at Site PVC162. Based on its extensive complex of quarries and workshops extending over $30 \mathrm{~km}^{2}$, Ixtepeque was potentially the most intensively exploited source of obsidian in southeast Mesoamerica (Graham and Heizer 1968; Sheets 1983:91; Sidrys et al. 1976; Williams et al. 1964:38).

Eight of the cores submitted for elemental analysis were attributed to sources in close proximity to the lower Cacaulapa Valley. Two distinct sources were identified, Source Y and San Luis. To date, Source Y has only been identified chemically, and no physical outcropping or quarry has been located. Given its chemical composition and visual characteristics, Source Y is probably quite close to the San Luis source, which is $20 \mathrm{~km}$ south of Site PVC162 (Aoyama et al. 1999).

More recently, Steven Shackley (Joyce et al. 2004) documented yet another outcropping on the eastern edge of the San Luis source area consisting of a large series of tuff domes. This outcropping, which Shackley designated as La Union after a nearby village, is situated above a tributary to the Quebrada Agua Helada from which Aoyama's group collected their San Luis sample. As the La Union and San Luis materials are chemically indistinguishable and physically adjacent, we, along with Hendon (2004:7), consider both to be part of the same extensive source and will refer to all of these outcroppings as San Luis. Currently, the presence of large nodules has yet to be noted in any of the descriptions of the San Luis source area.

The vast majority of the obsidian artifacts in the assemblage were identified as by-products of prismatic blade manufacture or the products 
Table 3. Prismatic Blades Tabulated by Segment and Source.

\begin{tabular}{lcccc}
\hline Segment & Ixtepeque & Chayal & San Luis & Subtotal \\
\hline Complete & 21 & - & - & 21 \\
Proximal & 141 & 5 & 5 & 151 \\
Medial & 142 & 2 & 6 & 150 \\
Distal & 103 & - & 4 & 107 \\
Fragment & 41 & 2 & 1 & 44 \\
Subtotal & 448 & 9 & 16 & 473 \\
\hline
\end{tabular}

themselves. The remainder is made up of the output from expedient flake-core technologies. In the entire assemblage, only eight artifacts were reshaped or modified by retouch. All of these were prismatic blades altered to form a haft or into pointed drill bits. No bifacially worked tools or bifacial thinning flakes were identified.

Prismatic blade segments were the most common type of chipped stone artifact recovered from this site (Table 3). Among other measures, calculation of cutting edge-to-mass ratios $(\mathrm{CE} / \mathrm{M})$ suggests that the efficient use of obsidian was a limited concern for the artisans of Site PVC162. Sheets and Muto (1972) first proposed this measure as a reflection of the efficiency with which blades were used, and Sidrys (1979) later applied this concept to indirectly assess ease of access to obsidian.

$\mathrm{CE} / \mathrm{M}$ calculations for prismatic blades of Site PVC162 were computed by doubling the lengths of all blades in the assemblage and dividing this figure by the total mass of blades. The higher the ratio, the harder it was to acquire blades and the more effort was devoted to conserving them. For our calculation (Table 4), we excluded specimens whose extremely small sizes resulted from postdepositional fracture or crushing. Included in this figure are 105 early termination prismatic blades. Although typically classified as blade production debris, they maintain the same morphology as blade segments. Therefore, we view early termination blades as potentially equivalent to blade segments in terms of their utility.

The CE/M ratios for Site PVC162 blades fall within the range of 5 to 7 for sites beyond $300 \mathrm{~km}$ from the source posited by Sidrys (1979:595). El Chayal lies more than $340 \mathrm{~km}$ away, and
Table 4. Characteristics of Prismatic Blades and Early Termination Flakes Combined and by Source.

\begin{tabular}{lcccc}
\hline & \multicolumn{5}{c}{$\begin{array}{c}\text { Cutting } \\
\text { Edge/ } \\
\end{array}$} & & & \\
& Mass & x-width & x-thick \\
& & $(\mathrm{cm})$ & $(\mathrm{cm})$ \\
\hline All & 534 & 3.6 & 1.29 & 0.28 \\
Blades & 429 & 4.1 & 1.21 & 0.27 \\
Early Termination & 105 & 2.3 & 1.63 & 0.32 \\
Ixtepeque & 510 & 3.6 & 1.29 & 0.28 \\
Chayal & 7 & 6.4 & 1.08 & 0.25 \\
San Luis & 17 & 4.2 & 1.26 & 0.30 \\
\hline & & & &
\end{tabular}

Ixtepeque is somewhat closer $(257 \mathrm{~km})$. Blade producers at Site PVC162 were less conservative with material from Ixtepeque. CE/M ratios for blades reduced from local sources $(20 \mathrm{~km})$ are much higher than anticipated. This discrepancy may result from the small sample size, although, as noted below, it probably has more to do with changing conditions of obsidian working and use.

Two other lines of evidence support the impression that efficient use of obsidian was not a pressing concern for inhabitants of Site PVC162. First, only five expedient percussion flakes show signs of moderate or heavy use-wear. Locally available chert was also relatively rare at the settlement. Limited use of obsidian and chert flakes tentatively implies that the available prismatic blades adequately met the needs of those engaged in tasks requiring stone tools. Second, of the blade segments recovered from this site, 60 had moderate or heavy use-wear. The low proportions of tools showing significant damage suggest that inhabitants were able to discard blade segments before use significantly altered their cutting edges.

Relative to other households in the lower Cacaulapa Valley, the volume of obsidian recovered from these structures is quite high. The quantity of blades recovered from Site PVC162, however, is low considering the number of exhausted cores at this site. The number of complete blades that can be reduced from a single core varies, but most estimates suggest a range of 100 to 180 blades produced per core (Clark 1986:36, 1997:154). The discrepancy between recovered blade segments and the vastly higher 
Table 5. Platform Preparation of Prismatic Blade Cores from Site PVC162.

\begin{tabular}{lccccr}
\hline Source & Ground & Striated & Untreated & Indeterminate & Total \\
\hline Ixtepeque & 13 & 27 & 1 & 1 & 42 \\
San Luis & 1 & 1 & - & - & 2 \\
Source Y & 3 & 3 & - & - & 6 \\
Not Sourced & 6 & 17 & 1 & 8 & 32 \\
Total & 23 & 48 & 2 & 9 & 82 \\
\hline
\end{tabular}

potential yield from the 82 cores suggests that, although manufactured at Site PVC162, very few blades were consumed or discarded there. This demonstrates that blades were not being produced in conjunction with another craft at this locale (Clark 1986:26). Moreover, it reinforces the notion that the goods manufactured by these artisans were distributed elsewhere.

The most outstanding feature of the assemblage is the quantity of exhausted prismatic blade cores retrieved from excavated contexts (Supplemental Table 1). Although some are partial fragments, many are complete or nearly so and retain well-preserved platforms, blade removal scars, and, in some cases, evidence for attempts at error removal. Of this assemblage, 21 prismatic cores were reused as expedient cores.

A growing body of literature (Clark 1982; Hirth 2003; Hirth and Andrews 2002; Hruby et al. 2011) has demonstrated that techniques used in manufacturing prismatic blades were not uniform across Mesoamerica. Nevertheless, there are a few common procedures that addressed recurring problems in reducing prismatic cores (Clark 1997; Clark and Bryant 1997; Crabtree 1968). These steps include platform rejuvenation, correction of blade removal errors, removal of inclusions, and platform preparation, all of which were identified in the Site PVC162 assemblage.

Platform treatment was a characteristic noted on most cores, complete artifacts, and proximal fragments. It took the form of grinding the entire surface or striating the edge of the platform; very rarely platforms were untreated (see Table 5; treatments of cores that did not retain a platform were recorded as Indeterminate).

Although striation or scratching was the most common preparation technique in the assemblage, ground platforms on cores are well repre- sented (Figure 8). A similar pattern is recorded on complete and proximal blade fragments. Of those sourced to Ixtepeque, nearly two-thirds $(64 \%)$ retain evidence of striation. For those artifacts obtained from local sources, the platform treatment is equally divided between ground and striated techniques.

Sheets (1983:95) noted for El Salvadoran assemblages that striation is the most common preparation technique during the Late Classic, with ground platforms increasing in frequency from the Terminal Classic into the Postclassic (AD 1100-1530). A similar chronological pattern is noted in central Mexico and western Mesoamerica (Healan 2009:104). Platform treatments, therefore, suggest that the occupation of Site PVC162 spans the Late Classic into the early part of the Terminal Classic. Given that excavated deposits in and around the site are relatively shallow, discerning the chronological relationships of contexts has been difficult. The absence of diagnostics that define the full Terminal Classic in the lower Cacaulapa Valley, especially Pachuca obsidian and Plumbate pottery, indicates that the occupation of Site PVC162 did not extend very far into this period (Urban 2016).

Aside from the chronological implications, it is clear that the initial treatment of raw materials and macro-cores varied by source. Cortex is noted with high frequency on cores, blades, and debris reduced from locally sourced obsidian. Among the 50 sourced cores, the only ones retaining cortex are from nearby flows. For all of the remaining unsourced cores, there are two fragments that retain cortex, and both have the same visual characteristics as the local San Luis or Source Y obsidian.

Analysis of the non-core chipped stone assemblage reinforces this pattern (Table 6). The few cortex-bearing artifacts reduced from 


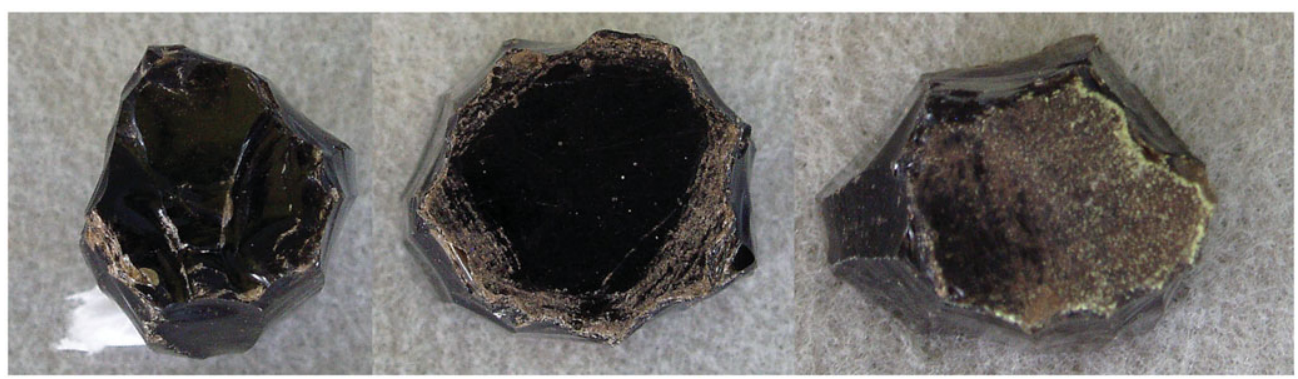

Figure 8. Platform treatments, left to right: platform rejuvenation, striation, and grinding. (Color online)

Table 6. Cortex-Bearing Obsidian Artifacts by Source.

\begin{tabular}{lccr}
\hline Source & Cortex & No Cortex & Totals \\
\hline Ixtepeque & 8 & 681 & 689 \\
Chayal & - & 10 & 10 \\
Perlite & 18 & 6 & 24 \\
San Luis & 34 & 37 & 71 \\
Subtotal & 60 & 734 & 794 \\
\hline
\end{tabular}

Ixtepeque material were classified as expedient percussion flakes, an initial series prismatic blade, or indeterminate shatter. In contrast, artifacts retaining cortex that were reduced from local sources include blade production debris as well as first and second series blades. A significant portion of the locally sourced obsidian includes blade production debris related to macro-core preparation.

Therefore, we can argue with some confidence that prismatic blade cores reduced from local sources were brought as nodules to the Site PVC162 workshop and then reduced to macrocores. It is striking that none of the cores or blade production debris sourced to Ixtepeque bear evidence of cortex. Put simply, materials originating from Ixtepeque and local sources were treated differently. This variation underscores the importance of recognizing heterogeneity in blade production technologies.

\section{Regional Segmentation of Blade Production}

Blade-core technologies were often regionally organized, with specialists coordinating their expertise to conduct specific stages of reduction (Braswell 2011:12; Hirth and Flenniken 2002:125). Our evidence supports a model in which blade production was regionally seg- mented for some but not all sources. Nearly all of the obsidian from Ixtepeque was imported to the Site PVC162 workshop as preformed macrocores. Presumably, specialists working in close proximity to the quarry at Ixtepeque undertook the initial stage of the blade production sequence. For obsidian obtained from local sources, preparation of macro-cores was undertaken at the workshop.

Thinking about how each step in this production sequence may vary spatially helps to explain why cores were, initially at least, being utilized from sources that are not geographically nearest to the workshop. Others describe the preferential importation of obsidian from Ixtepeque in terms of maintaining ties to the Copan polity or via other exchange networks (Aoyama et al. 1999; Hendon 2004). Although this may be the case, it fails to account for variation in the regional organization of prismatic blade technology. By extracting the raw materials and forming macro-cores, specialists at Ixtepeque would have enhanced the desirability of their products to blade producers during the Late Classic. The absence of specialists knapping macro-cores at local sources may well have made obsidian from these flows less preferable as it would have shifted the burden of initial core shaping to blade producers. Clark (1997:156) makes a similar argument about the preference for obsidian from the El Chayal source at Ojo de Agua despite its proximity to the San Martin Jilotepeque flows.

Few systematic investigations address how raw materials were quarried and macro-cores produced (Braswell 2004:182), and the precise nature of how commodities were exchanged 
across Late Classic southern and southeastern Mesoamerica is not clear. Most likely, Ixtepeque obsidian moved by various means, including direct exchanges between producers and consumers, the intervention of such middlemen as itinerant traders, and elite-funded trading expeditions (Feinman and Garraty 2010; Garraty 2010; Hirth 2008).

Whatever the mechanisms of exchange, there is good reason to believe that access to Ixtepeque macro-cores in the case of Site PVC162 relied at least indirectly on enduring inter-elite alliances that would have created the relatively peaceful conditions on which long-distance exchanges of all sorts depended. The relatively high volume of Ixtepeque obsidian at Site PVC162 and throughout the lower Cacaulapa Valley correlates with the Late Classic apogee of the El Coyote polity. Taken together with the CE/M ratios of Ixtepeque blades, it appears that the seventh through ninth centuries marked a period of relatively easy and reliable access by knappers at Site PVC162 to Ixtepeque macro-cores.

The ready availability of macro-cores from high-quality obsidian flows meant that the artisans at Site PVC162 did not rely on alternative sources of tool stone. Chert, for example, was not commonly used at Site PVC162 nor well represented in Late Classic assemblages throughout the lower Cacaulapa Valley. This regional economic structure was vulnerable to any perturbations that upset the flow of macrocores from quarries to knappers. Given the ubiquity of obsidian blades throughout the Late Classic lower Cacaulapa Valley, such disruptions would pose serious challenges to reproducing households and affiliations instantiated through work-party feasts.

\section{Shifting Patterns of Exchange and Production}

The abandonment of Site PVC162 apparently occurred during the Late to Terminal Classic transition in the ninth century. Among the lines of evidence suggesting this date are the ways in which the platforms of polyhedral cores were modified.

The high frequency of ground platforms on cores originating from sources near Site PVC162 may indicate that these outcrops were being exploited late in the history of the settlement possibly because its residents were struggling to acquire suitable material from distant Ixtepeque. The Late to Terminal Classic transition is marked throughout southern Mesoamerica by political fragmentation, population declines, and ruptures in long-distance trade (Demarest et al. 2005). The ninth-century abandonment of El Coyote's Late Classic monumental epicenter suggests that the polity was not immune to these processes (McFarlane 2005).

Obsidian from Ixtepeque may have no longer been reliably available due to these disruptions. In order to meet continuing demands for blades, knappers had to draw on sources and use skills they had not been called on to employ previously. Now, in addition to producing the blades, they first had to produce macro-cores. This interpretation accounts for the prevalence of both ground platforms and cortex on San Luis and Source Y cores, blades, and blade production debris from Site PVC162 (see Tables 5 and 6). It also explains why a significant portion of the locally sourced obsidian includes debris from macro-core preparation.

Variations in the frequencies of cortex and different platform treatments across materials from distinct sources highlight the importance of recognizing heterogeneity in blade production technologies even within one workshop. Such patterning may point to the shifting ways people engaged over time with suppliers of different raw materials.

In sum, residents of Site PVC162 demonstrated considerable skill as they innovatively employed new manufacturing procedures on materials they had previously deemed inferior to Ixtepeque obsidian. Given the apparent decline in elite power at El Coyote and elsewhere in southeast Mesoamerica during the ninth century, it seems reasonable to infer that artisans were now largely securing, working, and distributing obsidian tools within the lower Cacaulapa Valley on their own. Unable to acquire Ixtepeque obsidian, they participated in a more territorially restricted economic structure. Tasks that had been spatially segregated, such as macrocore preparation, were now conducted in the same workshop where blades were knapped. The anomalously high $\mathrm{CE} / \mathrm{M}$ ratio for local blades hints at the tenuousness of the new framework 
as even assets from nearby flows were being carefully conserved.

\section{Sequestered Craft Production and Shifting Political Economies}

We return to what first attracted us to Site PVC162: its isolated location. Sequestered blade workshops are rarely reported in Mesoamerica (cf. Burton 1987; Sheets 1972). Why would the occupants opt for such an unusual setting despite shifts in production technologies, sources of raw materials, and the decline of elite power at El Coyote? This locational strategy is especially puzzling as it set these artisans apart from potential consumers and high-ranking patrons.

The choice may have been part of a strategy to monopolize prismatic blade production. As the sole known suppliers of obsidian blades within the Late Classic lower Cacaulapa Valley, the inhabitants of Site PVC162 were in an excellent position to make themselves indispensable to elites and commoners. Their isolation from consumers, competitors, and notables would help guarantee such a monopoly over the knowledge needed to knap blades and, eventually, shape macro-cores. This putative exclusive control over the local distribution of a valued good may well have translated into the artisans' relative prominence as measured by the substantial architecture they could raise and valuables they could obtain.

Hiding from prying eyes came at a cost. Given the poor soils and difficulty accessing water that their location entailed, the inhabitants of Site PVC162 would have been dependent on others for basic resources. Whether or not they chose to live and work in such austere surroundings, this locale ensured the integrity of their monopoly while simultaneously undercutting their economic autonomy. As such, the power over others exercised by the residents of Site PVC162 was limited by their reliance on those same people for essential goods.

This relationship might have created a cycle in which survival and preeminence was dependent on their continued success in fashioning blades. When the changes that transpired during the Terminal Classic threatened their capacity to acquire raw materials, people improvised. They began using skills they had never employed before on materials they had previously rejected.
Although it did not prevent the abandonment of this household, these artisans' efforts emphasize the importance of blade-making to their continued survival as a distinct faction within lower Cacaulapa Valley society.

How, if at all, did the workshop relate to the political aspirations of the local rulers? These potentates, together with their ilk throughout southern and southeastern Mesoamerica, likely created the conditions for successful longdistance interactions in which the knappers thrived. That said, there is little evidence that these elites directly controlled the acquisition, production, and use of obsidian. If distances of workshops from elite residences and administrative facilities correlate with degrees of centralized control over these processes, the location of Site PVC162 was apparently an ostentatious expression of political independence. Workparty feasts were far more directly implicated in elite domination strategies, while the place of pottery production in these efforts remains unclear.

If artisans were relatively independent of elite control in the Late Classic, this was even more the case during the ninth century when the potentates of El Coyote seem to have experienced a sharp decline in their power. By this point, the artisans likely operated as autonomous agents, creatively, if ultimately unsuccessfully, maneuvering to maintain their specialized niche in a volatile lower Cacaulapa political economy. By the time a new political center emerged at $\mathrm{El}$ Coyote in the tenth century, there were no signs of obsidian blade manufacture at the center or in its environs (McFarlane 2005). However they came to live atop that hill, the residents of Site PVC162 for several centuries appear to have played an important economic role in supplying the lower Cacaulapa Valley with essential blades. Their place in the local power structure was, however, far more ambiguous.

\section{Conclusions}

There are several points following from this discussion that we think bear reiteration. First, this relatively small society exhibits considerable variability in how its component economic and political processes were related. The domestic 
economy pursued by numerous valley households contributed to their economic autonomy. Household independence was apparently counterbalanced by reliance on craft workshops for pottery and obsidian blades.

Manufacturing ceramic vessels might have been centered at the capital and could have been supervised by the rulers of El Coyote. There is, however, no clear evidence that this was the case. Obsidian blades, on the other hand, were fashioned well away from the center by craftworkers who probably monopolized the local manufacture and distribution of these tools. Exclusive local control over the industry provided these artisans with some power over those who used their products. While that dominion may have contributed to their material well-being, it was balanced by the artisans' dependence on their clients for basic subsistence.

Households, therefore, met most of their essential needs with the help of obsidian tools obtained from producers who were seemingly hard-pressed to feed themselves without the aid of those who relied on them for blades. At the same time, hierarchical relations were likely sustained by means of occasional overproduction of comestibles to support the workparty feasts through which expansive social identities were materialized. Enacting these gatherings, in turn, required access to obsidian blades.

Second, this complex political economy does not conform easily to models based on dichotomies between attached and independent specialists. These taxa define points within a matrix of possible relations among the production, exchange, and use of goods and the exercise of power. The Site PVC162 case reminds us that we should not get too comfortable with familiar models whose application may obscure more of past political economies than they illumine. Instead, we might profitably attend to questions of who was producing what goods, at what scales, and with what political and economic consequences.

Third, political economies are rarely static. Paying attention to variability within even this small lithic assemblage emphasizes the subtle but significant ways in which relations of power, production, exchange, and consumption can shift. Moreover, recognizing how processes of obsidian blade manufacture varied spatially reveals the ways in which technological systems can be regionally organized.

Fourth, the lower Cacaulapa Valley is hardly typical of Late Classic political economies in this region. For example, political centralization and hierarchy were apparently underwritten in the Naco Valley, $9 \mathrm{~km}$ to the northeast, by centralized control over several crafts, including blade manufacture (Schortman and Urban 1994; Schortman et al. 2001). The dispersal of power together with craft-working from that center during the Terminal Classic suggests that producing essential goods was both a means of exercising power over others and for resisting such pretensions (Ross 1997; Schortman and Urban 2004b, 2012).

In contrast, there is scant evidence of craft manufacture in the Late Classic middle Ulua drainage about $35 \mathrm{~km}$ south of the lower Cacaulapa Valley. Most probably, control over public rites by notables residing at the regional capital of Gualjoquito was one means by which they sought to overcome the relative economic autonomy of households under their command (Ashmore 1987; Schortman et al. 1986). This variation does not preclude a search for general statements concerning relations among political and economic processes. It does urge caution in advancing those claims, especially of adopting models derived from better-known areas, such as the Late Classic Maya Lowlands.

Fifth, unraveling ancient political economies requires investigating behavioral variation across entire polities. Pursuing extensive programs of survey and excavation is the only way we can hope to recognize the varied forms and histories of ancient political economies (Hirth 2013; Montmollin 1989; Smith 2004). That said, even ambitious field programs can easily miss those rare sites that hold the key to understanding political and economic forms. We came very close to not excavating Site PVC162, and there are other equally unprepossessing settlements on other hills that could yield finds challenging the interpretations presented here.

Acknowledgments. The excavations and analyses on which this report is based were conducted with the permission 
and support of our colleagues at the Instituto Hondureño de Antropología e Historia and with funding generously provided by the Foundation for the Advancement of Mesoamerican Studies (FAMSI), Kenyon College, and Johnson County Community College. We are very grateful for the support of these institutions and to the meticulous and indefatigable research of Charlie Webber and Leigh Anne Ellison who directed the excavations at Site PVC162. The residents of Pueblo Nuevo and Petoa were welcoming and helpful, as they have been since the inception of our work in the area during the summer of 1999. Fieldworkers from both towns, as well as other smaller locales in the area, did a superb job of unearthing the remains described herein. Any errors of omission or commission in this report are solely the authors' responsibilities.

Data Availability Statement. Obsidian analyzed for this study is archived in the Department of Anthropology at Johnson County Community College and in the Lima office of the Instituto de Hondureño Antropología e Historia.

Supplemental Material. Supplemental materials are linked to the online version of the manuscript, accessible via the SAA member login at https://doi.org/10.1017/laq.2017.53

Supplemental Table 1. Measurements and Characteristics for Analyzed Prismatic Cores.

\section{References Cited}

Aoyama, Kazuo, Toshiharu Tashiro, and Michael D. Glascock

1999 A Pre-Columbian Obsidian Source in San Luis, Honduras: Implications for the Relationship between Late Classic Maya Political Boundaries and the Boundaries of Obsidian Exchange Networks. Ancient Mesoamerica 10:237-249.

Ashmore, Wendy

1987 Cobble Crossroads: Gualjoquito Architecture and External Elite Ties. In Interaction on the Southeast Mesoamerican Frontier: Prehistoric and Historic Honduras and El Salvador, edited by Eugenia Robinson, pp. 28-48. British Archaeological Reports, Oxford.

1991 Site-Planning Principles and Concepts of Directionality among the Ancient Maya. Latin American Antiquity 2:199-226.

Ashmore, Wendy, and Jeremy Sabloff

2002 Spatial Orders in Maya Civic Plans. Latin American Antiquity 13:201-215.

Bernier, Hélène

2010 Craft Specialists at Moche: Organization, Affiliations, and Identities. Latin American Antiquity 21:2243.

Braswell, Geoffrey E.

2004 Lithic Analysis in the Maya Area. In Continuities and Change in the Maya Area: Perspectives at the Millennium, edited by Charles Golden and Gregory Borgsteade, pp. 177-199. Routledge, New York.

2011 The Technology of Ancient Maya Civilization. In The Technology of Maya Civilization: Political Economy and Beyond in Lithic Studies, edited by Zachary X. Hruby, Geoffrey E. Braswell, and Oswaldo Chinchilla Mazariegos, pp. 1-12. Equinox, Sheffield, England.
Braswell, Geoffrey E., John E. Clark, Kazuo Aoyama, Heather I. McKillop, and Michael D. Glascock

2000 Determining the Geological Provenance of Obsidian Artifacts from the Maya Region: A Test of the Efficacy of Visual Sourcing. Latin American Antiquity 11:269282.

Brumfiel, Elizabeth

1994 Factional Competition and Political Development in the New World: An Introduction. In Factional Competition and Political Development in the New World, edited by Elizabeth Brumfiel and John Fox, pp. 3-13. Cambridge University Press, New York.

Brumfiel, Elizabeth, and Timothy Earle

1987 Specialization, Exchange, and Complex Societies: An Introduction. In Specialization, Exchange, and Complex Societies, edited by Elizabeth Brumfiel and Timothy Earle, pp. 1-19. Cambridge University Press, Cambridge.

Burton, Susan S.

1987 Obsidian Blade Manufacturing Debris on Terrace 37. In Ancient Chalcatzingo, edited by David C. Grove, pp. 321-328. University of Texas Press, Austin.

Clark, John E.

1982 Manufacture of Mesoamerican Prismatic Blades: An Alternative Technique. American Antiquity 47:355376.

1986 From Mountains to Molehills: A Critical Review of Teotihuacan's Obsidian Industry. In Economic Aspects of Prehispanic Highland Mexico, Research in Economic Anthropology Supplement 2, edited by Barry L. Isaac, pp. 23-74. JAI Press, Greenwich, Connecticut.

1997 Prismatic Blademaking, Craftsmanship, and Production: An Analysis of Obsidian Refuse from Ojo de Agua, Chiapas, Mexico. Ancient Mesoamerica 8:137159.

Clark, John E., and Donne Bryant

1997 A Technological Typology of Prismatic Blades and Debitage from Ojo de Agua, Chiapas, Mexico. Ancient Mesoamerica 8:111-136.

Clark, John E., and William J. Parry

1990 Craft Specialization and Cultural Complexity. Research in Economic Anthropology 12:289346.

Costin, Cathy L.

1991 Craft Specialization: Issues in Defining, Documenting, and Explaining the Organization of Production. In Archaeological Method and Theory, Volume 3, edited by Michael Schiffer, pp. 1-56. University of Arizona Press, Tucson.

2001 Craft Production Systems. In Archaeology at the Millennium: A Sourcebook, edited by Gary Feinman and T. Douglas Price, pp. 273-327. Kluwer Academic/Plenum Publishers, New York.

Crabtree, Donald

1968 Mesoamerican Polyhedral Cores and Prismatic Blades. American Antiquity 33:446-478.

Demarest, Arthur A., Prudence M. Rice, and Don S. Rice (editors)

2005 The Terminal Classic in the Maya Lowlands: Collapse, Transition, and Transformation. University Press of Colorado, Boulder.

Dietler, Michael

2010 Archaeologies of Colonialism: Consumption, Entanglement, and Violence in Ancient Mediterranean France. University of California Press, Berkeley. 
Ekholm, Kajsa

1972 Power and Prestige: The Rise and Fall of the Kongo

Kingdom. SKRIV Service AB, Uppsala, Sweden.

Feinman, Gary M.

1995 The Emergence of Inequality: A Focus on Strategies and Process. In Foundations of Social Inequality, edited by T. Douglas Price and Gary M. Feinman, pp. 255-279. Plenum Press, New York.

2013 Crafts, Specialists, and Markets in Mycenaean Greece. Reenvisioning Ancient Economies: Beyond Typological Constructs. American Journal of Archaeology 117:453-459.

Feinman, Gary M., and Christopher P. Garraty

2010 Preindustrial Markets and Marketing: Archaeological Perspectives. Annual Review of Anthropology 39:167-191.

Friedman, Jonathan, and Michael Rowlands

1978 Notes toward an Epigenetic Model of the Evolution of Civilization. In The Evolution of Social Systems, edited by Jonathan Friedman and Michael Rowlands, pp. 201-276. University of Pittsburgh Press, Pittsburgh.

Garraty, Christopher P.

2009 Evaluating the Distributional Approach to Inferring Marketplace Exchange: A Test Case from the Mexican Gulf Lowlands. Latin American Antiquity 20: $157-174$

2010 Investigating Market Exchange in Ancient Societies: A Theoretical Review. In Archaeological Approaches to Market Exchange in Ancient Societies, edited by Christopher P. Garraty and Barbara L. Stark, pp. 3-32. University Press of Colorado, Boulder.

Gosden, Chris

2004 Archaeology and Colonialism: Cultural Contact from $5000 \mathrm{BC}$ to the Present. Cambridge University Press, Cambridge.

Graham, John A., and Robert F. Heizer

1968 Notes on the Papalhuapa Site, Guatemala. Contributions of the University of California Archaeological Research Facility 5:101-125.

Healan, Dan M.

2009 Ground Platform Preparation and the "Banalization" of the Prismatic Blade in Western Mesoamerica. Ancient Mesoamerica 20:103-111.

Hendon, Julia A.

2004 Importation of Obsidian at Cerro Palenque, Honduras: Results of an Analysis by EDXRF. Paper presented at the 7th Seminario de Antropología Hondureña, Tegucigalpa.

Hirth, Kenneth G.

1996 Political Economy and Archaeology: Perspectives on Exchange and Production. Journal of Archaeological Research 4:203-239.

1998 The Distributional Approach: A New Way to Identify Marketplace Exchange in the Archaeological Record. Current Anthropology 39:451-476.

2003 Experimentation and Interpretation in Mesoamerican Lithic Technology. In Mesoamerican Lithic Technology, edited by Kenneth G. Hirth, pp. 3-9. University of Utah Press, Salt Lake City.

2008 The Economy of Supply: Modeling Obsidian Procurement and Craft Provisioning at a Central Mexican Urban Center. Latin American Antiquity 19:435-457.

2010 Finding the Mark in the Marketplace: The Organization, Development, and Archaeological Identification of Market Systems. In Archaeological Approaches to Market Exchange in Ancient Societies, edited by Christopher
P. Garraty and Barbara L. Stark, pp. 227-247. University Press of Colorado, Boulder.

2013 Economic Consumption and Domestic Economy in Cholula's Rural Hinterland, Mexico. Latin American Antiquity 24:123-148.

Hirth, Kenneth G., and Bradford Andrews (editors)

2002 Pathways to Prismatic Blades: A Study in Mesoamerican Obsidian Core-Blade Technology. Cotsen Institute of Archaeology, University of California, Los Angeles.

Hirth, Kenneth G., and J. Jeffrey Flenniken

2002 Core-Blade Technology in Mesoamerican Prehistory. In Pathways to Prismatic Blades: A Study in Mesoamerican Obsidian Core-Blade Technology, edited by Kenneth G. Hirth and Bradford Andrews, pp. 121-129. Cotsen Institute of Archaeology, University of California, Los Angeles.

Hruby, Zachary X., Geoffrey E. Braswell, and Oswaldo Chinchilla Mazariegos (editors)

2011 The Technology of Maya Civilization: Political Economy and Beyond in Lithic Studies. Equinox, Sheffield, England.

Joyce, Rosemary A., Julia A. Hendon, and Jeanne Lopiparo 2009 Being in Place: Intersections of Identity and Experience on the Honduran Landscape. In The Archaeology of Meaningful Places, edited by Brenda J. Bowser and María Nieves Zedeño, pp. 53-72. University of Utah Press, Salt Lake City.

Joyce, Rosemary, M. Steven Shackley, Kenneth McCandless, and Russ Sheptak

2004 Resultados Preliminares de una Investigación con EDXRF de Obsidiana de Puerto Escondido. In Memoria del VII Seminario de Antropología de Honduras "Dr. George Hasemann”, edited by Kevin Rubén Ávalos, pp. 115-130. Instituto de Hondureño Antropología e Historia, Tegucigalpa.

Masson, Marilyn A., and David A. Freidel (editors)

2002 Ancient Maya Political Economies. AltaMira Press, Walnut Creek, California.

McFarlane, William J.

2005 Power Strategies in a Changing World: Archaeological Investigations of Early Postclassic Remains at El Coyote, Santa Barbara, Honduras. PhD dissertation, Anthropology Department, State University of New York, Buffalo.

McFarlane, William J., Charles Webber, and Leigh Anne Ellison

2005 Socio-Political Implications of an Isolated BladeWorkshop: Commodities, Control, and Specialization. Paper presented at the 70th Meeting of the Society for American Archaeology, Salt Lake City, Utah.

Moholy-Nagy, Hattula

2011 Observations on the Use-Life Trajectory of Lithic Artifacts at Tikal, Guatemala. In The Technology of Maya Civilization: Political Economy and Beyond in Lithic Studies, edited by Zachary X. Hruby, Geoffrey E. Braswell, and Oswaldo Chinchilla Mazariegos, pp. 30-36. Equinox, Sheffield, England.

Montmollin, Olivier de

1989 The Archaeology of Political Structure: Settlement Analysis in a Classic Maya Polity. Cambridge University Press, Cambridge.

Moore, Jerry D.

1996 Architecture and Power in the Ancient Andes: The Archaeology of Public Buildings. Cambridge University Press, Cambridge. 
Peregrine, Peter

1991 Some Political Aspects of Craft Specialization. World Archaeology 23:1-11.

Rice, Prudence M.

2009 Late Classic Maya Pottery Production: Review and Synthesis. Journal of Archaeological Method and Theory 16:117-156.

Ross, Neil A.

1997 Cores in the Periphery: Obsidian and Sociopolitical Hierarchy in the Naco Valley, Northwest Honduras. Master's thesis, Department of Anthropology, Arizona State University, Tempe.

Saitta, Dean J.

1994 Agency, Class, and Archaeological Interpretation. Journal of Anthropological Archaeology 13:201-227.

Schiffer, Michael B.

1972 Archaeological Context and Systemic Context. American Antiquity 37:156-165.

Schortman, Edward M., and Patricia A. Urban

1994 Living on the Edge: Core/Periphery Relations in Ancient Southeastern Mesoamerica. Current Anthropology 35:401-430.

2004a Modeling the Roles of Craft Production in Ancient Political Economies. Journal of Archaeological Research 12:185-226.

2004b Opportunities for Advancement: Intra-Community Power Contests in the Midst of Political Decentralization in Terminal Classic Southern Mesoamerica. Latin American Antiquity 15:251-272.

2011 Networks of Power: Political Relations in the Late Postclassic Naco Valley, Honduras. University Press of Colorado, Boulder.

2012 Enacting Power through Networks. Journal of Anthropological Archaeology 31:500-514.

Schortman, Edward M., Patricia A. Urban, Wendy Ashmore, and Julie Benyo

1986 Interregional Interaction in the Southeast Maya Periphery: The Santa Barbara Archaeological Project 1983-1984 Seasons. Journal of Field Archaeology 13:259-272.

Schortman, Edward M., Patricia A. Urban, and Marne Ausec

2001 Politics with Style: Identity Formation in Prehispanic Southeastern Mesoamerica. American Anthropologist 103:312-330.

Sheets, Payson D.

1972 A Model of Mesoamerican Obsidian Technology Based on Workshop Debris in El Salvador. Ceramica de Cultura Maya 8:17-33

1975 Behavioral Analysis and the Structure of a Prehistoric Industry. Current Anthropology 16: 369-391.

1983 Guatemalan Obsidian: A Preliminary Study of Sources and Quirigua Artifacts. In Quirigua Reports, Vol. II, edited by Robert J. Sharer, pp. 87-101. University of Pennsylvania Museum, Philadelphia.

2003 The Behavioral Model in Maya Core-Blade Technology. In Mesoamerican Lithic Technology, edited by Kenneth G. Hirth, pp. 10-14. University of Utah Press, Salt Lake City.

Sheets, Payson D., and Guy R. Muto

1972 Pressure Blades and Total Cutting Edge: An Experiment in Lithic Technology. Science 175(4022):632634.

Sidrys, Raymond

1979 Supply and Demand among the Classic Maya. Current Anthropology 20:594-597.
Sidrys, Raymond, John Andresen, and Derek Marcucci 1976 Obsidian Sources in the Maya Area. Journal of New World Archaeology 1:1-13.

Smith, Michael E.

2004 The Archaeology of Ancient State Economies. Annual Review of Anthropology 33:73-102.

Stark, Barbara L., and Christopher P. Garraty

2010 Detecting Marketplace Exchange in Archaeology: A Methodological Review. In Archaeological Approaches to Market Exchange in Ancient Societies, edited by Christopher P. Garraty and Barbara L. Stark, pp. 3358. University Press of Colorado, Boulder.

Stark, Miriam T.

1992 From Sibling to Suki: Social Relations and Spatial Proximity in Kalinga Pottery Exchange. Journal of Anthropological Archaeology 11:137-151.

Stockett, Miranda K.

2005 Practicing Identities: Modeling Affiliation on Multiple Social Scales at Late Classic (A.D. 650-960) Las Canoas, Honduras. PhD dissertation, Anthropology Department, University of Pennsylvania, Philadelphia.

Urban, Patricia A.

2007 Rural Production in Northwest Honduras: The 2004 Season of the Lower Cacaulapa Valley Archaeological Project. Foundation for the Advancement of Mesoamerican Studies. Electronic document, http://www.famsi. org/reports/03030/index.html, accessed September 18, 2017.

2016 Political Economy in Late and Terminal Classic Southeastern Mesoamerica: Putting the El Coyote Copper Smelting Workshop in Its Regional Context. Economic Anthropology 3:240-253.

Urban, Patricia A., Marne Ausec, and E. Christian Wells

1997 The Fires Without and the Fires Within: Evidence for Ceramic Production Facilities at the Late Classic Site of La Sierra, Naco Valley, Northwestern Honduras, and in Its Environs. In The Prehistory and History of Ceramic Kilns, edited by Prudence M. Rice, pp. 173-194. American Ceramics Society, Westerville, Ohio.

Urban, Patricia A., Edward M. Schortman, Aaron N. Shugar, and Laura Richardson

2013 The Production of Copper at El Coyote, Honduras: Processing, Dating, and Political Economy. In Archaeometallurgy in Mesoamerica: New Perspectives and Approaches, edited by Scott E. Simmons and Aaron N. Shugar, pp. 77-112. University Press of Colorado, Boulder.

Wells, E. Christian

2003 Artisans, Chiefs, and Feasts: Classic Period Social Dynamics at El Coyote, Honduras. PhD dissertation, Department of Anthropology, Arizona State University, Tempe.

2004 Investigating Activity Patterns in Prehispanic Plazas: Weak Acid-Extraction ICP/AES Analysis of Anthrosols at Classic Period El Coyote, Northwest Honduras. Archaeometry 46:67-84.

2006 Recent Trends in Theorizing Prehispanic Mesoamerican Economies. Journal of Archaeological Research 14:265-312.

2007 Faenas, Ferias, and Fiestas: Ritual Finance in Ancient and Modern Honduras. In Mesoamerican Ritual Economy: Archaeological and Ethnological Perspectives, edited by E. Christian Wells and Karla DavisSalazar, pp. 29-65. University Press of Colorado, Boulder. 
2010 Sampling Design and Inferential Bias in Archaeological Soil Chemistry. Journal of Archaeological Method and Theory 17:209-230.

Williams, Howel, A. R. McBirney, and Gabriel Dengo

1964 Geologic Reconnaissance of Southeastern Guatemala. University of California Publications in Geological Sciences 50:1-54.
Wolf, Eric R.

1990 Distinguished Lecture: Facing Power-Old Insights, New Questions. American Anthropologist 92:586-596.

Submitted November 11, 2016; Revised February 21, 2017; Accepted August 17, 2017 